\title{
Natura 2000 sites in the Polish Carpathians vs local development: inevitable conflict?
}

\author{
Agata Warchalska-Troll \\ Keywords: Natura 2000, Polish Carpathians, local development, conservation conflicts
}

\section{Abstract}

This paper discusses the results of a study on the influence of Natura 2000 sites on local development, as emerge from analyses of the content of Management Plans (MPs) for 40 sites located in the Polish Carpathians, as well as from case studies and documentary evidence, including administrative decisions connected with Natura 2000. Particular attention is given to those topics and stakeholders that dominate the public debate on MPs, potential and existing threats as identified in MPs, implementation suggestions for local plans and strategies, and how regulations are applied during the realization of any spatial development. The main findings suggest that Natura 2000 acts as a break on proposed spatial development only in very specific locations where high biological values meet sports facilities and settlement development pressure. Nevertheless, large-scale conflicts could potentially appear in forestry and the management of waterways.

\section{Introduction}

As in Western countries generally, in Poland we observe a so-called paradigm shift in nature protection (Rodary \& Castellanet 2003; Mose 2007), modifying considerably the rigid post-socialist institutional structures and procedures which until recently were still very visible in CEECs (Kluvánková-Oravská et al. 2009). Undoubtedly, accession to the EU was a key modifier in this respect for the whole region, as, inter alia, many new funding and grant opportunities emerged for institutions such as national parks or biosphere reserves, bringing not only money but also encouragement for a participative approach in project management (see e.g. Švajda 2008; Szabo et al. 2008). However, the new integrative approach has hardly been applied in the context of the EU-wide Natura 2000, even though this network was initially designed to reconcile socio-economic development with the prevention of the gradual loss of biodiversity in Europe (Council of European Communities 1992). In practice, Natura 2000 has attracted strong criticism for a disproportionately high priority given to conservation goals, to the neglect of the human perspective (Hirschnitz-Garbers \& Stoll-Kleemann 2011). This was also the case of Poland: although the Natura 2000 network was developed there over several years from 2004 when the country became an EU member, the final phase of the designation of sites proceeded quickly and in a very top-down manner, based, moreover, on obsolete data. In addition, the creation of the sites was not preceded by any large-scale educational and information campaign, even though the network covered large areas of private land (Kamal et al. 2013). As a result, Natura 2000 soon provoked numerous social conflicts throughout the country (Grodzińska-Jurczak \& Cent 2011), which was to some extent unsurprising, as similar problems had already been reported elsewhere, for example in France (Charbonneau 1997),
Finland (Hiedanpää 2002), Germany (Eben 2006) and Ireland (Visser et al. 2007). These circumstances, resulting in little input from the local people concerned, became a serious drawback for the network's proper implementation (Kati et al. 2014).

Some of the above-mentioned aspects have already been described either at a national level or through particular case studies, especially with regard to governance and participation issues (e. g. Cent et al. 2014); so, too, has the perception of Natura 2000 (e.g. GrodzińskaJurczak \& Cent 2011; Pietrzyk-Kaszyńska et al. 2012). However, we are still lacking a broader perspective on the possible impact of Natura 2000 on the development of Polish communities that would present the initial concerns in light of the actual facts. Such studies are only now becoming possible, as the network has entered a new stage: the challenging process of preparation, consultation and implementation of the Management Plans (MPs) for particular sites which will regulate their functioning (that is, also formulate restrictions and requirements). Although this process is ongoing, we can summarize its first phase, with a special focus on the compulsory public discussion that accompanies the preparation of MPs. Our approach looks at the following detailed research questions:

What topics and which stakeholders dominate in the public consultations concerning Natura 2000 sites?

- What potential and existing threats and pressures concerning local development were identified for Natura 2000 sites that already had MPs in force, and, as a consequence, what are the main changes which should be made to local plans and strategies of spatial development because of Natura 2000?

- To what extent does Natura 2000 complicate the spatial development process?

In order to answer these questions without being distracted by too many detailed circumstances, the Pol- 


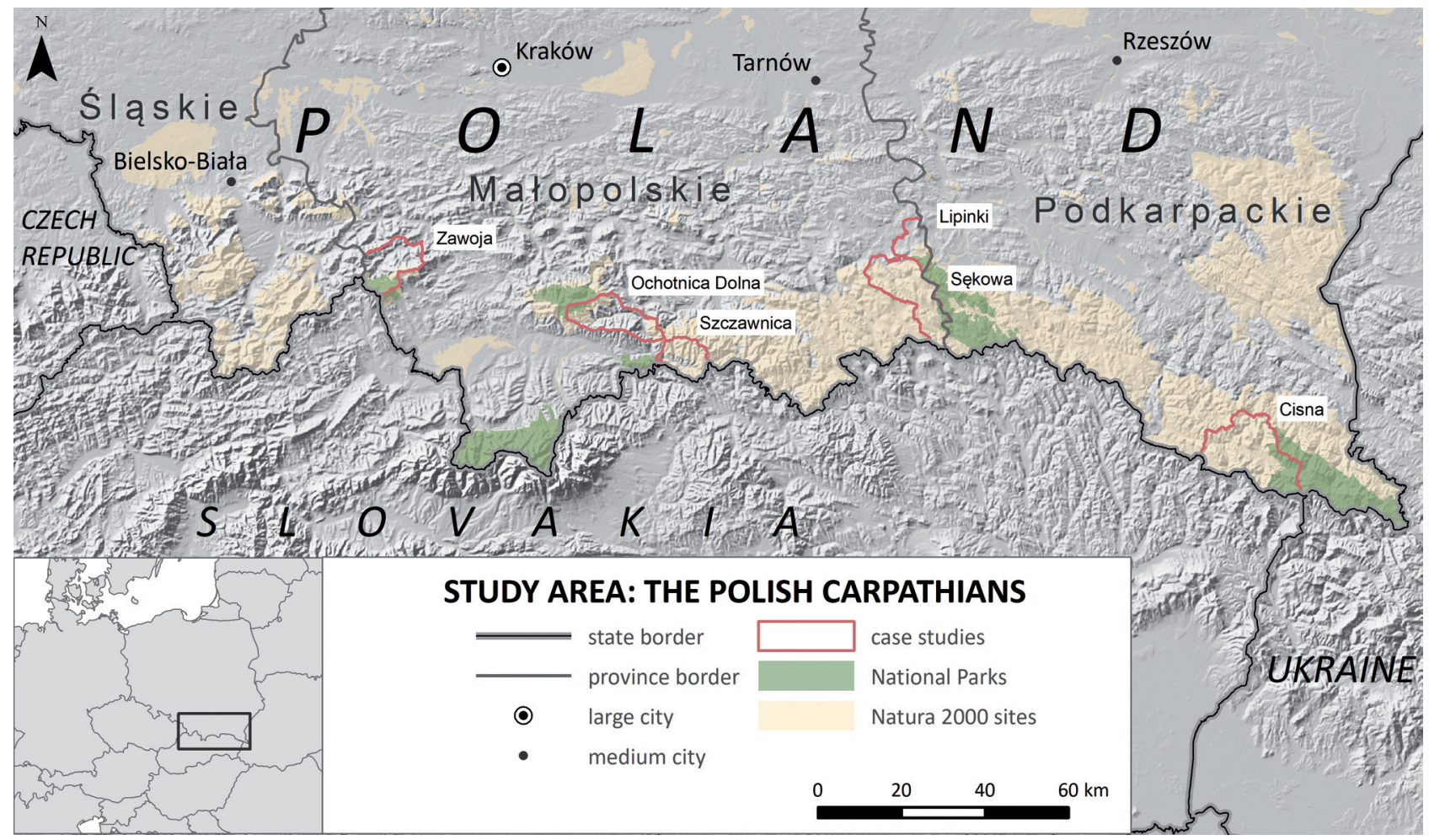

Figure 1 - Location of municipalities selected for case studies, against the background of the Natura 2000 and National Parks network in the Polish Carpathians. Design: Agata Warchalska-Troll \& Mateusz. Troll 2018. Database: EEA/EU-DEM/Państwowy Rejestr Granic CODGiK (bttp:/ / www.codgik.gov.pll)

ish Carpathians were chosen as a research area. This part of the Carpathian mountain range, being situated within one state, presents a single legal framework, as well as similar (though not identical) environmental and cultural contexts.

\section{Data sources and methods}

The main data source for the analyses described in this paper (Table 1) is a set of MPs of all 40 Natura 2000 sites in the Polish Carpathians that had already come into force by mid-July 2017 (MPs for other Natura 2000 sites were still in preparation at the time). These legal documents were prepared for the Regional Directorates for Environmental Protection (RDEPs) (governmental agencies operating on regional level) by private consulting companies, associations or institutions specializing in environmental assessment. These entities are chosen, by law, after calls for tender have been made (which means that the cost is an important factor that RDEPs need to consider when choosing who is going to prepare a MP). As MPs are official legal documents, they are publicly available. They include the following sections:

1. detailed description of the borders and a map of the site;

2. identification of existing and potential threats and pressures to habitats and species that are subjects of protection within the site;

3. protection goals;
4. description of planned protection actions;

5. suggested changes in local and regional plans / strategies of spatial development (this is an optional section as such suggestions are not always necessary);

6. statement about the need to prepare a protection plan (a more detailed document than a MP; this section is also optional);

7. in this study, we investigate sections 2) and 5).

Contrary to the Natura 2000 network designation phase, during the preparation of MPs for particular sites public consultation is mandatory. In practice, this requirement is fulfilled through:

1. public meetings (usually three, organized during the preparation of a MP) enabling questions and debate, and therefore intended to be a platform for a compromise until the plan is ready; the outcome of these meetings is not, however, binding for the final shape of the MP;

2. official written comments on the proposed project of a MP by interested parties; each comment submitted this way has to be included in the final version of the MP in a dedicated section; it must also be formally and officially responded to, with a clear statement regarding the extent to which the proposition was included in the final MP; if an idea was rejected, an explanation has to be given as to why.

In this study we are going to look closely only at official comments (point two above), as these can be 
Table 1 - Summary of the main sources for data on Natura 2000 used in the study. MPs - Management Plans

\begin{tabular}{|c|c|c|c|c|}
\hline & $\begin{array}{l}\text { MPs } \text { for Natura } 2000 \text { sites in } \\
\text { the Polish Carpathians } \\
\text { Number of items: } 40 \\
\text { (all MPs valid as at } 15.07 .2017 \\
\text { were considered) }\end{array}$ & $\begin{array}{l}\text { Official written comments on } \\
\text { the proposed MP project by } \\
\text { interested parties during public } \\
\text { consultation; } \\
46 \mathrm{MPs} \text { considered (all that } \\
\text { had undergone the procedure } \\
\text { between } 2008 \text {, when the legal } \\
\text { framework was adopted in } \\
\text { Poland, and 15.07.2017) } \\
\text { Number of items: } 817 \text { sepa- } \\
\text { rate documents submitted }\end{array}$ & $\begin{array}{l}\text { The set of administrative deci- } \\
\text { sions made by RDEPs in Car- } \\
\text { pathian provinces (Małopolskie } \\
\text { and Podkarpackie)c as a result } \\
\text { of environmental assessment } \\
\text { concerning the potential impact } \\
\text { of planned developments on } \\
\text { Natura } 2000 \\
\text { Number of items: } 1847 \\
\text { (476-Matopolskie; } 1371 \text { - } \\
\text { Podkarpackie) }\end{array}$ & \multirow{2}{*}{$\begin{array}{l}\text { Individual in-depth or semi- } \\
\text { structured interviews and queries } \\
\text { of source materials conducted } \\
\text { within the framework of } 6 \text { case } \\
\text { studies of selected Carpathian } \\
\text { municipalities } \\
\text { Number of items: } 55 \text { (inter- } \\
\text { views) } \\
\text { Note: this part of the research } \\
\text { was of supplementary impor- } \\
\text { tance for this study; its aim was } \\
\text { to gain additional insight into } \\
\text { the context of the analyses }\end{array}$} \\
\hline & $\begin{array}{l}\text { 1. Categorizing (grouping) } \\
\text { selected threats and pressures } \\
\text { described in the MPs (only } \\
\text { issues connected with socio- } \\
\text { economic development were } \\
\text { considered) } \\
\text { 2. Categorizing (grouping) } \\
\text { implementation suggestions } \\
\text { for local and regional spatial } \\
\text { plans and strategies }\end{array}$ & $\begin{array}{l}\text { 1. Distinguishing separate com- } \\
\text { ments within } 817 \text { documents } \\
\text { (the total of } 997 \text { reflects the } \\
\text { fact that sometimes a docu- } \\
\text { ment contained more than } \\
\text { one comment/ topic) } \\
\text { 2. Categorizing and group- } \\
\text { ing topics of comments and } \\
\text { stakeholders who submitted } \\
\text { them }\end{array}$ & $\begin{array}{l}\text { Summarizing the results (calcu- } \\
\text { lating the statistics) }\end{array}$ & \\
\hline
\end{tabular}

a Original Polish name: Plany zadań ochronnych

${ }^{b}$ Of these, 6 MPs had already been replaced by new, updated plans, but for this part of the analysis they were still useful.

"For the RDEP of Slaskie province (the third Carpathian province), only a general statement, without particular records, was obtained.

compared more easily, because of their formal character and standardized form, than protocols from public meetings, although the latter provided additional interesting insight into the background to various conflicts. Official comments were also $100 \%$ publicly available, which was not always the case for protocols from public meetings.

The third important source of information used here is the database of administrative decisions made by RDEPs in two Carpathian provinces (Małopolskie and Podkarpackie) concerning the potential impact on Natura 2000 of the proposed developments. According to current Polish regulations, all plans for development within Natura 2000 sites or their vicinity that are potentially harmful for habitats and species protected by EU directives undergo a procedure of environmental assessment. This data is available on request. In the case of the RDEP in the third Polish Carpathian province, Śląskie, no exact data was obtained (only a general statement that no proposals were rejected, because no negative impacts on Natura 2000 habitats were foreseen).

Additionally, the author conducted 6 case studies of municipalities that have Natura 2000 sites (and National Parks) on their territory: Zawoja, Ochotnica Dolna, Szczawnica, Lipinki, Sękowa, Cisna (Figure 1). These case studies were based on 55 individual indepth interviews or semi-structured interviews with local and regional stakeholders. Because the aim of this part of the research was to gain a deeper insight into relationships between protected areas and their social context, and not to deliver measurable data, the set of respondents presented here is not a representative sample. The field research also covered observations, and analysis of local documents (such as spatial planning / management documents and strategies, protocols from the archives of public consultation meetings, local press).

\section{Results}

Stakeholders' involvement and perspectives

As already mentioned, the first stage of public consultation about the final shape of MPs included public meetings during the initial preparation of the plan. However, not only was the outcome of these meetings not binding, but also, as interviews conducted within the case studies showed, it appeared unsatisfactory to many stakeholders. These circumstances may at least partially explain a generally high social involvement in the second stage of the public consultation, during which a total of 817 official comments (separate documents) were submitted to MP projects (an average of almost 18 per MP).

When we explore the share of comments submitted by particular stakeholders (Figure 2), four main groups can be identified: State Forests $(27 \%$ of comments), General Directorate for Environmental Protection $(22 \%)$, scientists/experts $(20 \%)$ (this group includes scientists from universities and research institutes as well as members of NGOs dedicated to nature protection), and finally local authorities / administration and communities (19\%). Within the last category, about a half of the comments came from the municipal authorities/administration, while the rest came from private individuals and smaller local bodies such as village councils and representatives of land / forest owners' associations. As comments made by the General Directorate for Environmental Protection (governmental institution operating at national level, above RDEPs) are mostly of a technical and formal (legal/ procedural) character, we can conclude 


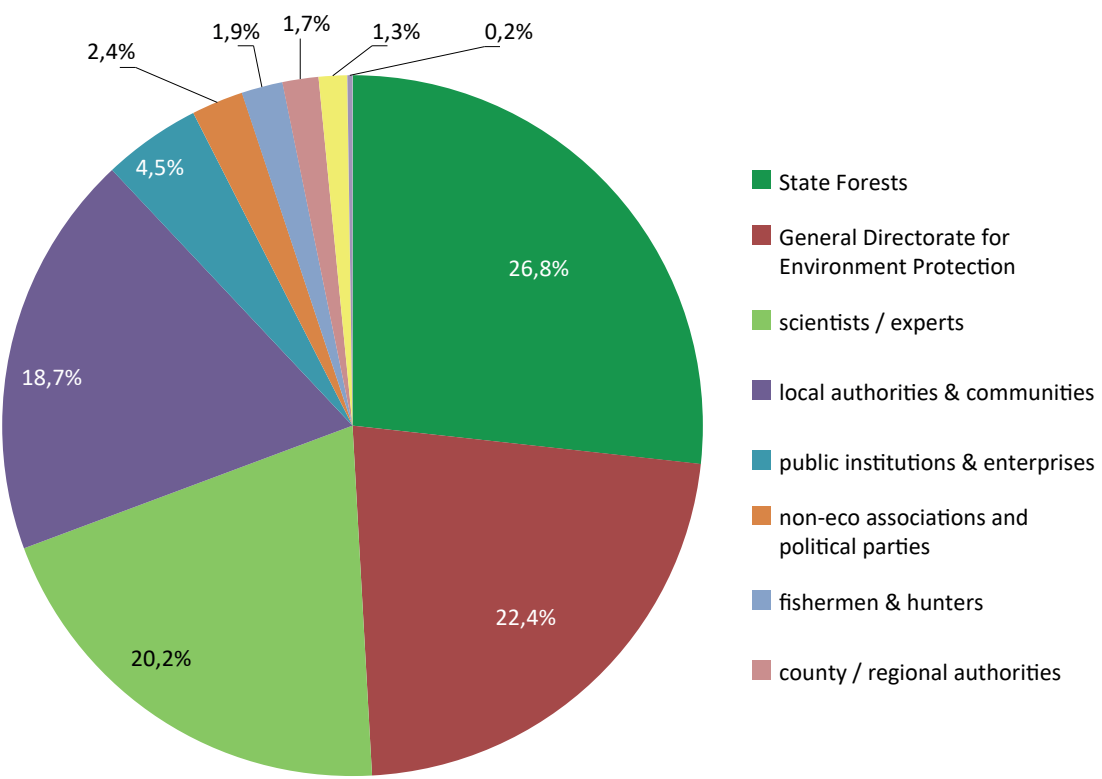

Figure 2 - Share of total comments officially submitted by stakeholder groups to RDEPs concerning MPs for Natura 2000 sites during the public consultation process $(n=817)$

that, so far, discussion of the final shape of MPs is dominated by the State Forests, scientists / experts and local communities (including their elected representatives). Their varying interests, concerns and expectations emerge clearly when we compare the thematic profiles of issues raised by local communities during this stage of public consultation (which is of special interest in this study) with those coming from other stakeholder groups (Figure 3).

Issues of Natura 2000 site borders as well as procedural and formal notes emerged as the most frequent among those raised by local communities, followed by hydrotechnical issues (mostly the regulation of watercourses) and forestry. Borders seem crucial for the local inhabitants, and most of all the local administration, since they are believed to affect many other fields of interest such as settlement and infrastructure development or access to areas and particular sites. This means that local communities are, in general, not conscious that in the case of Natura 2000 special focus is given not to official site boundaries but to preventing threats (to habitats and species protected within the site), including those within or coming from the immediate vicinity of the site. In other words, limits may be placed on proposed developments taking place outside the boundaries, even when their negative impact on habitats and protected species is merely a potential one (European Commission 2000, p. 27). This proves that the idea of the Natura 2000 network, its character and principles are still not well enough known by people generally, and the sites are perceived through a classical paradigm of island conservation. In the author's opinion, based on the interviews conducted within the framework of the case studies, previous experience of other types of protected area with high protection status influences these attitudes. According to Polish

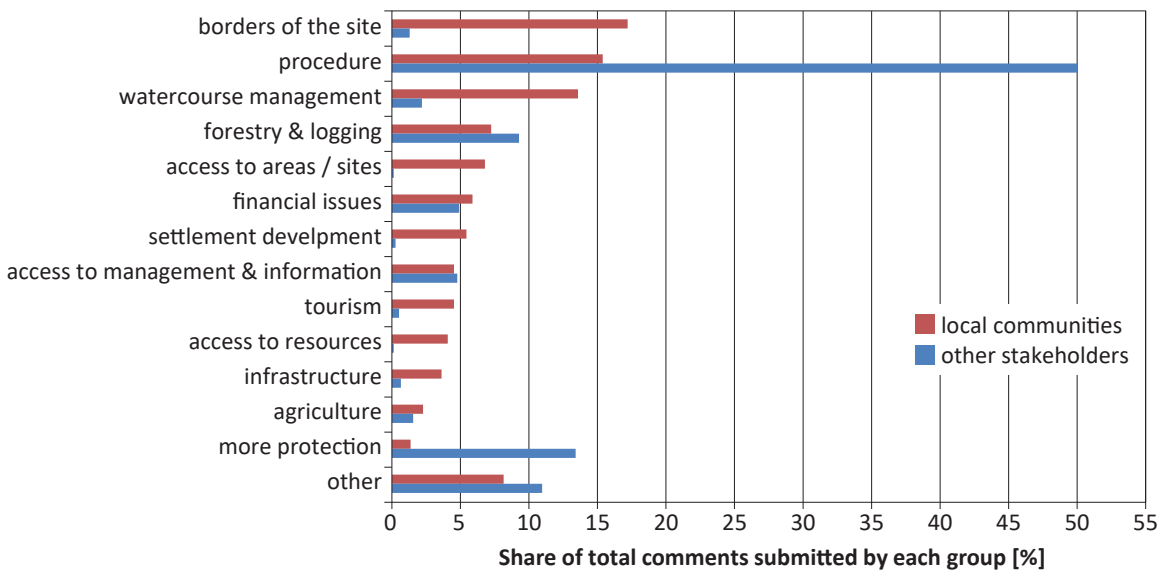

Figure 3 - Thematic structure of local people's vs total comments concerning MPs for Natura 2000 submitted to RDEPs during the public consultation process $(n=997)$. 


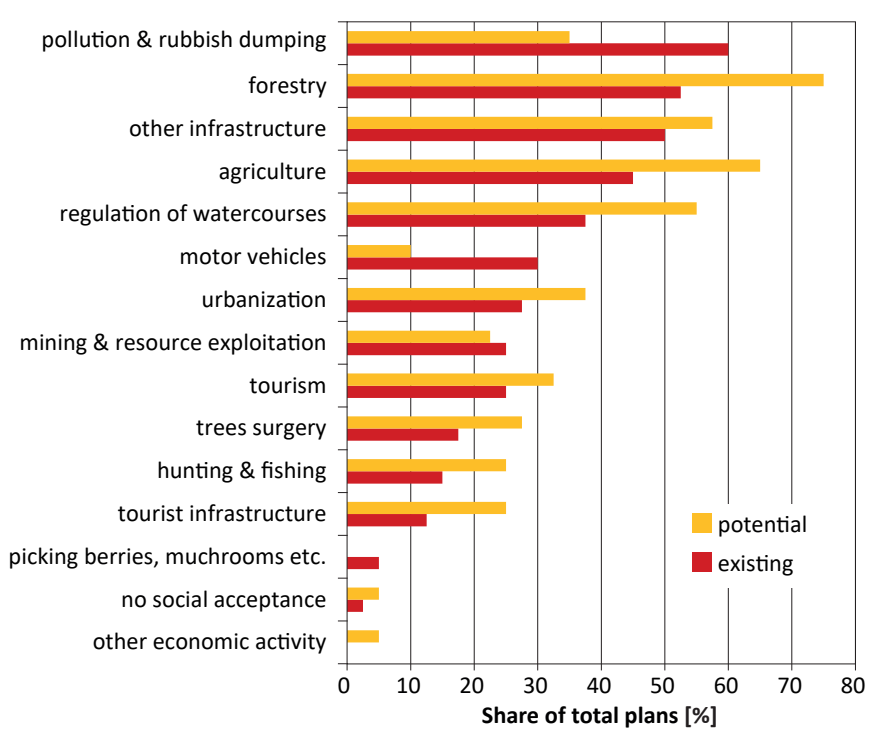

Figure 4 - Potential and existing threats and pressures to the species and habitats protected within Natura 2000, as identified in MPs $(n=40)$. Note: Threats and pressures presented by natural or environmental processes (e.g. climate change or invasive species) were not investigated. law, in the case of national parks and nature reserves, restrictions focus much more (compared to Natura 2000) on the territory itself (Sejm RP 2004).

The high share of procedural and formal notes (in both stakeholder groups) is, on the one hand, a sad illustration of the quality of documents produced within a procedure that requires calls for tender. On the other hand, in many cases it is indicative of the dissatisfaction and frustration of some stakeholders who felt neglected at the stage of public meetings, as many comments included complaints about the framework, scope and quality of communication and information provided during meetings (e. g. no / not enough access to data sources and methodologies used during site evaluations, the formulation of restrictions, late information about meeting dates and places, inaccurate protocols, differences between the content presented during meetings and the final version of MPs). Such remarks did not directly address the project of the MP itself, and therefore were not usually taken into consideration in the final MP (this lack of direct relevance to the MP is one of the main reasons behind the high rate of comment rejection, almost $1 / 3)$. The remarkably high proportion of comments concerning watercourse regulation and forestry reflects very clearly the physical character of the area, where villages are usually located in narrow valleys with mountain rivers prone to sudden floods, and surrounded by forests that are a source of income for a considerable number of local people. Interestingly, the explicit expression of financial concerns or ones concerning tourism development is not common.

This general picture was confirmed, by and large, during the field studies and interviews, although the focus of concerns varied according to the character of the site and the habitats / species protected. Sites dedicated to the protection of summer colonies of bats (which are often located in old wooden churches), although small, often provoked conflicts, as they included urbanized areas (e. g. in case of the municipality of Szczawnica). The compromise with local communities was also hard to achieve, notably in the case of river habitats.

Impact of Natura 2000 on development emerging from MPs and RDEPs' decisions

\section{Identifying threats and pressures concerning local development}

When we compare the concerns and attitudes outlined above to the existing threats and pressures on the subjects of protection (species and habitats) as identified in MPs (Figure 4), we observe that indeed forestry and the regulation of watercourses were evaluated as fairly important threats, although more often potential than existing. By contrast, urbanization (settlement development) and tourism - and here especially tourist infrastructure, so issues that were of concern during the initial conflict - are found lower down the list. It is also interesting that only four categories were identified more often as existing threats than as potential ones: 1) pollution and rubbish dumping (fly-tipping or at legally recognized sites); 2) motor vehicles operating within the site (usually specified as the use of off-road motor vehicles on forest roads causing noise, pollution and soil / plant-cover degradation); 3) mining and resource exploitation (in most cases, this concerned exploitation of gravel from the streams and river channels); 4) picking berries and mushrooms (which was less connected with the protection of species directly destroyed in this way than with the penetration of habitats by humans).

Pressures and threats resulting from agriculture need a little further explanation, as this factor was considered in MPs under three general dimensions: 1) land abandonment/lack of certain (usually traditional) land-use practices such as grazing; 2) farming practices or land-use patterns (e.g. meadows vs arable lands); 3 ) intensification of farming, including the use of artificial fertilizers. While 1) was usually considered 


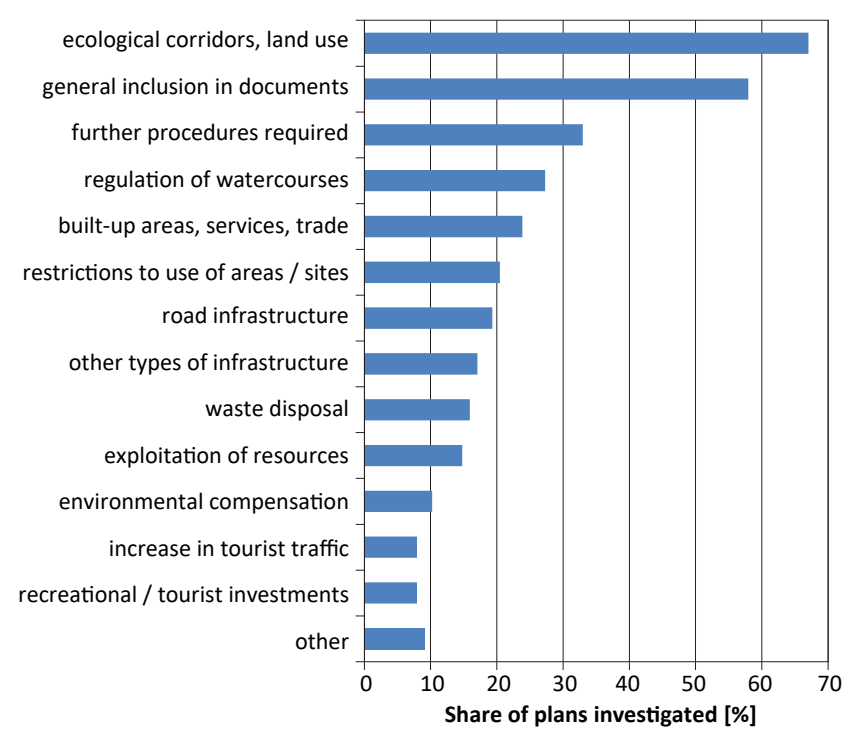

Figure 5 - Topics of implementation suggestions concerning local / regional plans and strategies of spatial development included in MPs for Natura 2000 sites $(n=24)$. Note: $n=24$ [not 40, the total number of MPs analysed] because a section dedicated to implementation suggestions for local plans and strategies of spatial development was not an obligatory part of a MP. to be an existing threat, 2) and 3) usually fell into the category of potential ones. Therefore, the real current problem with agriculture in the Polish Carpathians in relation to nature conservation is that due to the lack of certain human activities, important semi-natural habitats are being lost. This problem was addressed by the EU with financial subsidies for several types of organic farming and Natura 2000 habitat-friendly management. However, as the case studies (which included interviews with farmers and shepherds) showed, these incentives have so far had very limited success in the mountains, being very formalized and inflexible. For example, respondents in the village of Ochotnica Górna - where traditional sheep grazing, which was practised in this area for centuries, has recently been re-introduced through bottom-up initiatives - admitted that following Natura 2000 principles very closely is difficult as sheep grazing is highly dependent on the weather, and in the mountains this varies (sometimes dramatically) between seasons. Sticking to rules such as mowing deadlines or deadlines for moving flocks of sheep from one pasture to another, drawn up by external experts, is sometimes impossible, which has direct consequences on the payment of subsidies. Similar problems concerning cattle grazing in meadows protected within the Natura 2000 network were also reported from the municipality of Lipinki.

\section{Changes concerning local plans and strategies of spatial development suggested in MPs for Natura 2000 sites}

The overview of threats and pressures is to a large extent compatible with implementation suggestions for local plans and strategies of spatial development included in MPs (Figure 5), as requests for ecological corridors and concerns regarding land use were closely connected with maintaining forest cover and agricultural practices. One of the main differences concerns the issue of pollution and waste, which, after being identified as an important existing threat to protected species and habitats (Figure 4), was then treated marginally when it came to precise implementation suggestions. We should also note here that the category general inclusion in documents usually contained very general statements regarding the presence or not of Natura 2000 sites in local / regional spatial development plans and strategies. A further procedures required statement was another frequent general comment reminding local authorities that, for some proposed developments, investigation of their potential impact on Natura 2000 sites is required and would be evaluated by the RDEP.

\section{Natura 2000 vs spatial development}

The fear that Natura 2000 would be an obstacle to the development of local infrastructure used to be a widely-used argument against the network, as reported in studies on its social perception (Grodzińska-Jurczak \& Cent 2011, p. 15), reinforced by the fact that for the first time ever in Poland a protected area of high priority covered large areas of private land (Kamal et al. 2013). However, in practice, this potentially negative impact of Natura 2000 was not confirmed within the area of study, even though some regional and subregional differences remain.

The data on administrative decisions made by RDEPs in connection with Natura 2000 enabled the most in-depth investigation in the case of Małopolskie province (Figure 6). As evidenced, only around 1\% $(1.2 \%)$ of the development projects submitted to the RDEP within the 7-year period ended up being reject$\mathrm{ed}$, and the vast majority were not even subjected to additional procedures of environmental evaluation, these procedures being applied mostly for large infrastructural and industrial projects, and housing development (housing estates in environmentally sensitive areas).

In Podkarpackie province, the picture is similar: of 1371 decisions made, almost 81\% (1105) ended with approval, with no additional requirements, and only $2.3 \%$ project proposals were rejected. However, 


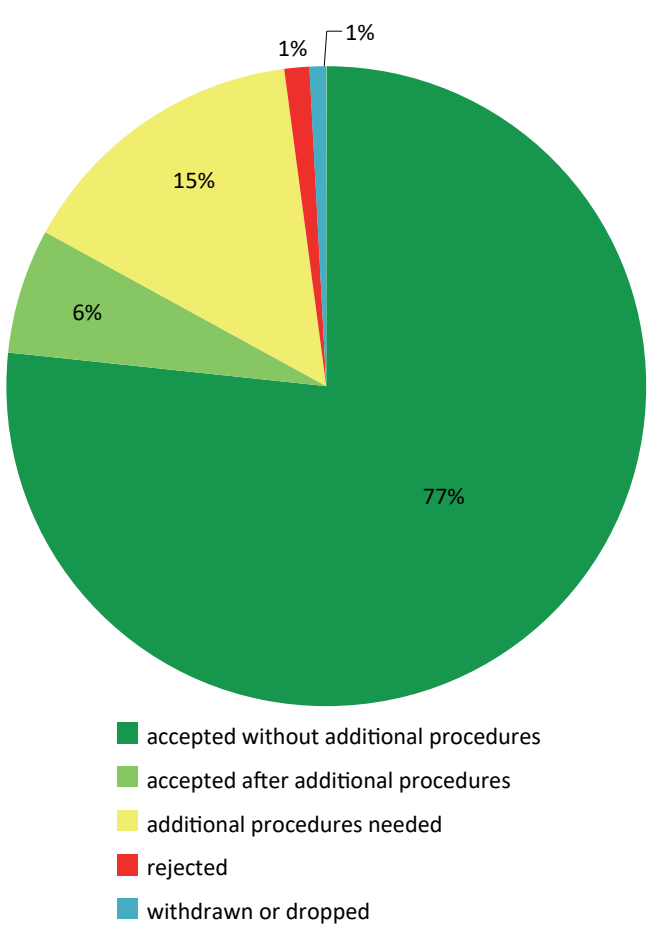

Figure 6 - Status of spatial development projects submitted to the RDEP in Matopolskie province between 2009 and end of 2016 in connection with their potential impact on Natura $2000(n=476)$.

among the 31 rejection cases, 16 concerned the municipality of Cisna in the Bieszczady Mountains. This is a high and exceptional concentration of negative decisions. Cisna was closely investigated as a case study, which showed that high environmental and landscape values clash there with intense settlement development pressure. In recent decades, this municipality has also seen several conflicts concerning extensive plans for ski resort development, so far successfully blocked by nature protection organizations. As for the third Carpathian province, Śląskie (Silesia), according to the data provided by the RDEP, no proposals were rejected.

\section{Discussion}

Numerous conflicts around the implementation of Natura 2000, once evoked, cast a dark shadow over the further negotiation process. However, as some other studies have shown, large-scale problems and sources of conflict often stay hidden at the beginning and only emerge in more detailed analyses. For instance, a survey led by Grodzińska-Jurczak and Cent (2011) within selected Polish municipalities, including in the Carpathians, showed that concerns about Natura 2000 limiting the development of tourism were mostly expressed by local authorities / administration representatives (especially in the mountains). At the same time, inhabitants were less critical about the idea of nature protection and were generally convinced that protected areas support tourism develop- ment, although some feared obstacles in their immediate neighbourhood, such as not being able to build a house on their own parcel. Nevertheless, as proved by Pietrzyk-Kaszyńska et al. (2012), previous experiences with protected areas within a particular community may locally modify these attitudes. Such influence was also very visible in the present case studies, e. g. in Zawoja and Szczawnica. Moreover, flood prevention as well as forestry and logging were revealed in this study as important issues while some other authors (Grodzińśka-Jurczak \& Cent 2011; PietrzykKaszyńska et al. 2012) did not pay too much attention to them.

The findings outlined above focus our attention on two particular questions: whose voices are really heard, and whose views are expressed through public consultation concerning nature protection? As we have demonstrated, local-level stakeholders submitted (only) 19\% of the comments on MPs, and were thus considerably less active than e.g. the State Forests; and of these comments by local stakeholders, barely half came directly from the people concerned. Even though participation is not a universal solution to solve the challenges posed by biodiversity management (Lawrence 2008; Wallner \& Wiesmann 2009), we have to bear in mind that in post-socialist countries such as Poland, public consultation generally (i. e. not only in the case of nature conservation) is still far from the desired level, is often criticized for being too formalized and superficial, and is not properly addressed or managed (Pawłowska \& Staniewska 2014; Kotus 2013; Damurski 2012).

Against such a background, public consultation concerning Natura 2000 in Poland, although started with a delay, should still be considered advanced in terms of the efforts being made to increase social empowerment, especially in Małopolskie province (Cent et al. 2014). From a broader perspective, the imbalances in biodiversity governance, especially the over-representation of powerful players in the public debate on environmental issues, have proved a problem both in developing countries (Ramiarantsoa \& Rodary 2011) and in Europe, and also, interestingly, irrespective of the specific economic and cultural contexts (Paloniemi et al. 2015). Based on such observations, and on the growing role of large conservationist NGOs in particular (which was also apparent in this study), some authors even suggest that the paradigm shift towards a more integrative and socially inclusive approach to nature conservation has recently been replaced by a back to barriers tendency (Aubertin et al. 2011). The question of whether Natura 2000 will soon become a classic example of the latter or, rather, evolve towards a parks of the future idea (Hammer et al. 2016), becoming managed in a way similar to UNESCO biosphere reserves (Stoll-Kleemann et al. 2010) or UNESCO World Natural Heritage sites (Conradin \& Wiesmann 2014), remains open. 


\section{Conclusions}

In mountain areas, exceptional environmental values and high biodiversity meet harsh living conditions and often, at the same time, intense anthropic pressure on development, especially in the fields of tourism and recreation. This seems to lead to an inevitable clash with conservation goals. However, this study shows that the significance usually attributed in this respect to projects such as ski lifts or other tourist and recreation facilities is in fact limited to very specific places. The influence of Natura 2000 on hydrotechnical development in particular, on watercourse management more generally, and on forestry is likely to have much broader socio-economic consequences for communities in the Polish Carpathians. A more widely-approved consensus on eco-friendly anti-flood solutions is recommended in narrow mountain valleys, along with sustainable use of forests, which are the main richness of the region in both economic and biological sense. Incentives addressing the management of high-value meadows and extensive farming, additionally embracing the protection of the cultural landscape and traditional activities like sheep and cattle grazing, could be at least a partial solution. Such ideas can work, though more thanks to the personal determination of local leaders than to a supportive institutional environment. Finally, although communities and decision-makers are gradually becoming familiar with Natura 2000 and realizing that it is not a universal obstacle to any development, there is still a lot to be done in terms of information and education. Focusing local people's attention on the opportunity to limit negative behaviours that devastate their little homeland (pollution, dumping rubbish, cultural landscape loss, noise pollution, dangers on forest roads posed by off-road vehicles...) is likely to be more successful than promising them that a protected area may provide direct material benefits. Such promises may simply be ineffective, as some recent evidence shows (Michel 2017).

Natura 2000 will probably never work in the same way as a national park in terms of being an in-field institution that provides projects, workplaces, services and goods (Mika et al. 2015). However, if treated in a less bureaucratic manner, promoted more positively, and supported by (not necessarily purely monetary) compensation and incentives, it may still function well in vulnerable mountain communities.

\section{References}

Aubertin, C., F. Pinton \& E. Rodary 2011. Introduction: Sustainable Development, A New Age for Conservation? In: Aubertin, C. \& E. Rodary (eds.), Protected Areas, Sustainable Land?: 1-9. Farnham \& Burlington.

Cent, J., M. Grodzińska-Jurczak \& A. PietrzykKaszyńska 2014. Emerging multilevel environmental governance - A case of public participation in Poland. Journal for Nature Conservation 22: 93-102.

Charbonneau, S. 1997. Natura 2000: Une opportunité de dialogues à saisir. Courrier de l'environnement de I'INRA 32: 78-81. [In French]

Conradin, K. \& U. Wiesmann 2014. Does World Natural Heritage status trigger sustainable regional development efforts? eco.mont 6(2): 5-12.

Damurski, Ł. 2012. Polish Planners' Attitudes Towards Citizen Participation. Problemy ekorozwoju - problems of sustainable development 7 (2): 87-96. [In Polnish]

Eben, M. 2006. Public participation during site selections for Natura 2000 in Germany: The Bavarian case. In: Stoll-Kleemann, S. \& M. Welp (eds.), Stakeholder dialogues in natural resources management-Theory and practice: 261-276. Berlin-Heidelberg.

European Commission 2000. Managing Natura 2000 sites. The provisions of Article 6 of the 'Habitats' Directive 92/43/CEE. Luxembourg.

Grodzińska-Jurczak, M. \& J. Cent 2011. Expansion of nature conservation areas - problems with Natura 2000 implementation in Poland? Environmental Management 47: 11-27.

Hammer, T., I. Mose, D. Siegriest \& N. Weixlbaumer 2016. Parks of the future - Which future parks in Europe? In: Hammer, T., I. Mose, D. Siegriest \& N. Weixlbaumer (eds.), Parks of the Future. Protected Areas in Europe Challenging Regional and Global Challenge: 1322. München.

Hiedanpää, J. 2002. European-wide conservation versus local well-being: the reception of the Natura 2000 Reserve Network in Karvia, SW-Finland. Landscape and Urban Planning 61: 113-123.

Hirschnitz-Garbers, M. \& S. Stoll-Kleemann 2011. Opportunities and barriers in the implementation of protected area management: a qualitative meta-analysis of case studies from European protected areas. The Geographical Journal 177(4): 321-334.

Kamal, S., W. Tokarz \& M. Grodzińska-Jurczak 2013. Tereny prywatne w ochronie przyrody: dotychczasowe dobre praktyki i rozwiązania. Chronmy prayrode ojczysta 69(4): 275-284. [In Polnish]

Kati, V., T. Hovardas, M. Dieterich, P.L. Ibisch, B. Mihok \& N. Selva 2014. The challenge of implementing the European network of protected areas Natura 2000. Conservation Biology 29(1): 260-270.

Kluvánková-Oravská, T., V. Chobotová, I. Banaszak, L. Slavikova \& S. Trifunovova 2009. From Government to Governance for Biodiversity: The Perspective of Central and Eastern European Transition Countries. Environmental Policy and Governance 19: 186-196.

Kotus, J. 2013. Position of the Polish city on the ladder of public participation: Are we going the right way? The case of Poznan. Cities 35: 226-236.

Lawrence, A. 2008. Experiences with participatory conservation in post-socialist Europe. International Journal of Biodiversity Science \& Management 4(4): 179-186. 
Michel, A. 2017. "What is a national park for?" Principles of worth in a Swiss national park project. Presentation delivered at the plenary session 'Parks \& People' at the $6^{\text {th }}$ Symposium for Research in Protected Areas, 2.-3.11.2017. Salzburg (AT).

Mika, M., R. Pawlusiński \& B. Zawilińska 2015. Park narodowy a gospodarka lokalna. Model relacji ekonomicznych na przykładzie Babiogórskiego Parku Narodowego. Kraków. [In Polish]

Mose, I. (ed.) 2007. Protected Areas and Regional Development in Europe. Towards a New Model for the $21^{\text {st }}$ Century.

Paloniemi, R., E. Apostolopoulou, J. Cent, D. Bormpoudakis, A. Scott, M. Grodzińska-Jurczak, J. Tzanopoulos, M. Koivulehto, A. Pietrzyk-Kaszyńska \& J.D. Pantis 2015. Public Participation and Environmental Justice in Biodiversity Governance in Finland, Greece, Poland and the UK. Environmental Policy and Governance 25: 330-342.

Pawłowska, K. \& A. Staniewska 2014. Social participation in urban planning in Polish cities. Dissertations of Cultural Landscape Commission 23: 109-134.

Pietrzyk-Kaszyńska, A., J. Cent, M. GrodzińskaJurczak \& M. Szymańska 2012. Factors influencing perception of protected areas - The case of Natura 2000 in Polish Carpathian communities. Journal for $\mathrm{Na}$ ture Conservation 20: 284- 292.

Ramiarantsoa, H.R. \& E. Rodary 2011. Conclusion: Understanding Protected Areas in Globalisation. In: Aubertin C. \& E. Rodary (eds.) Protected Areas, Sustainable Land?: 167-176. Farnham \& Burlington.

Rodary, E. \& Ch. Castellanet 2003. Introduction. Les trois temps de la conservation. In: Rodary, E., Ch. Castellanet \& G. Rossi (eds.) Conservation de la nature et le développement. L'intégration impossible?: 5-44. Paris. [n French].

Sejm RP 2004. Ustawa z dnia 16 kwietnia 2004 r. o ochronie przyrody, Dz. U. 2004 nr 92 poz. 880. Warsaw. [In Polnish]
Stoll-Kleemann, S., A.C. de la Vega-Leinert \& L. Schultz 2010. The role of community participation in the effectiveness of UNESCO Biosphere Reserve management: evidence and reflections from two parallel global surveys. Environmental Conservation 37(3): 227-238.

Švajda, J. 2008. Participatory conservation in a post-communist context: The Tatra National Park and Biosphere Reserve, Slovakia. International Journal of Biodiversity Science \& Management 4(4): 200-208.

Szabo, E.A., A. Lawrence, C. Iusan \& S. Canney 2008. Participatory protected area management - A case study from Rodna Mountains National Park, Romania. International Journal of Biodiversity Science \& Management 4(4): 187-199.

The Council of European Communities, 1992. Council Directive 92/43/EEC of 21 May 1992 on the conservation of natural habitats and of wild fauna and flora. Official Journal of European Communities, No. L 206/7, Brussels.

Visser, M., J. Moran, E. Regan, M. Gormally \& S. Skeffington 2007. The Irish agri-environment: how turlough users and non-users view converging EU agendas of Natura 2000 and CAP. Land Use Policy 24(2): 362-373.

Wallner, A. \& U. Wiesmann 2009. Critical Issues in Managing Protected Areas by Multi-Stakeholder Participation - Analysis of a Process in the Swiss Alps. eco.mont 1(1): 45-50.

\section{Author}

\section{Agata Warchalska-Troll}

a geographer and a $\mathrm{PhD}$ student at the Institute of Geography and Spatial Management of the Jagiellonian University in Krakow, Poland. She also works at the National Institute for Spatial Policy and Housing as the managing editor of the quarterly journal Urban Development Issues. 